\title{
KARAKTERISTIK HABITAT DAN DISTRIBUSI ASAM HALUBI (Eleiodoxa conferta)(Griff) Burret 1942, DESA BINANGA DUA KEC. SILANGKITANG KABUPATEN LABUHANBATU SELATAN
}

\author{
Rivo Hasper Dimenta ${ }^{1 *}$, Jahrina ${ }^{1)}$, Rusdi Machrizal ${ }^{1)}$ \\ ${ }^{1)}$ Pendidikan Biologi-Fakultas Keguruan dan Ilmu Pendidikan Universitas Labuhanbatu, \\ e-mail: rivohd11@gmail.com
}

\begin{abstract}
This research aims to determine the habitat characteristics and the distribution of halubi (Eleiodoxa conferta) in Binanga village, Silangkitang subdistrict of Labuhanbatu Selatan Regency. In an effort to sampling, this study using explore descriptive method. Halubi (E. conferta) found to be analyzed morphological characteristics of stems, leaves, flowers, fruit, and seeds. Measurement of physicalchemical parameters performed in situ. The distribution of halubi (E. conferta) is found 2 point in this village, with the character environment such as temperature $\left(31-32{ }^{\circ} \mathrm{c}\right)$, air humidity $(68-72 \%), \mathrm{pH}$ of the soil $(5,5-6,9)$, as well as the type of soil in the form of peat young and clay.
\end{abstract}

Keywords: Binanga Dua, Characteristic Morphology, Eleiodoxa conferta

\begin{abstract}
Abstrak
Penelitian ini bertujuan untuk mengetahui karakteristik habitat tumbuh tanaman halubi (Eleiodoxa conferta) serta daerah persebaran tumbuhan halubi (E. conferta) di Desa Binanga Dua, Labuhanbatu Selatan. Pengkoleksian halubi dilakukan dengan metode jelajah. Halubi (E. conferta) yang ditemukan diidentifikasi karakteristik morfologi berupa batang, daun, bunga, buah, dan biji. Pengukuran parameter fisik-kimia dilakukan secara insitu. Hasil penelitian menunjukkan distribusi halubi $(E$. conferta) ditemukan pada 2 titik, dengan karakter lingkungan suhu $\left(31-32^{\circ} \mathrm{C}\right)$, kelembaban udara $(68$ $72 \%)$, $\mathrm{pH}$ tanah $(5,5-6,9)$, serta tipe tanah berupa gambut muda dan liat
\end{abstract}

Kata kunci : Eleiodoxa conferta, Halubi, Morfologi, Desa Binanga Dua

\section{PENDAHULUAN}

Halubi atau asam paya (Eleiodoxa conferta) merupakan spesies tumbuhan yang tergolong famili aracaceae, dimana morfologinya menyerupai tanaman nipah dengan ketinggian maksimal sehingga 5 meter. Daun pelepah keluar dari batang perdu dan mempunyai daun berwarna hijau yang lurus dengan susunan saling berhadapan sepanjang 1.5 meter dan lebar 3-5 cm. Panjang pelepah daun sekitar 3-4 meter dan pelepah akan mati apabila ketiak pelepah telah mengeluarkan bunga dan buah. Pelepah daun ditutupi oleh duri dengan panjang antara 5-7 cm. Akar tanaman ini berupa akar serabut, dan antar batang tanaman ini tumbuh rapat (Griffith W (1844); Dransfield et al (2008).

Banyak tumbuh-tumbuhan dan buah-buahan sekitar yang mampu dijadikan untuk menyokong kesejahteraan masyarakat sebagai pemasukan tambahan, contohnya adalah buah halubi (E. conferta) (Afriani et al., 2014). Buah ini selain digunakan untuk tambahan bumbu perasa dalam makanan tradisional, dapat pula dijadikan manisan, untuk dipasarkan sebagai tambahan penghasilan. Menurut Wardani (2008) manisan halubi (E. conferta) yang belum dikemas dipasaran, dijual dengan harga $\mathrm{Rp} 10.000$,-/500 gr, sedangkan dalam gelas kemasan berukuran $240 \mathrm{ml}$ dijual dengan harga Rp 3.000,-/gelas. Namun sumberdaya alam hayati 
yang cukup tinggi kini mulai terancam punah keberadaannya dikarenakan terjadinya pembalakan liar dan perambahan kawasan habitat tumbuh. Salah satu tanaman yang terdampak adalah asam halubi (E. conferta) ini, dimana kini tanaman tersebut sudah mulai jarang ditemukan.

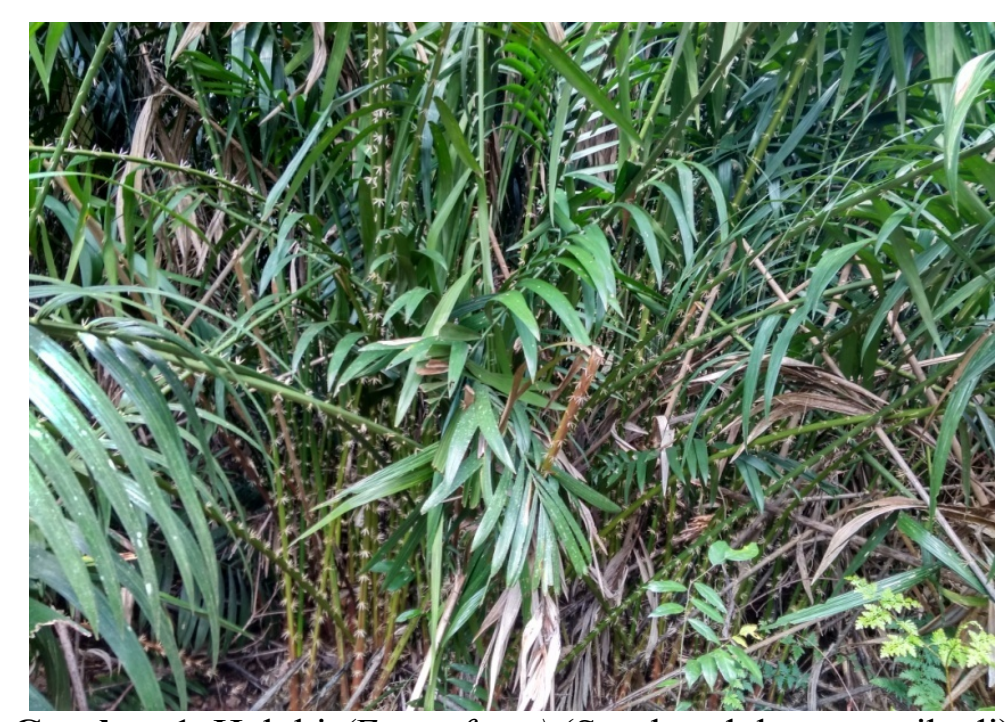

Gambar 1. Halubi (E. conferta) (Sumber dokumen pribadi)

Distribusi halubi di dunia menurut informasi ditemukan di Borneo, Malaysia, Thailand, dan Indonesia (Lim, 2011). Lokasi tumbuh halubi di Indonesia hanya berada di pulau Sumatera Dransfield et al (2008). Desa lokasi penelitian Binanga Dua merupakan salah satu desa yang terdapat di Kecamatan Silangkitang Kabupaten Labuhanbatu Selatan, Sumatera Utara. Berdasarkan informasi masyarakat sekitar desa, tumbuhan halubi (E. conferta) tumbuh secara liar di areal sekitar hutan dan di rawa desa Binanga Dua. Hasil wawancara diketahui hingga saat ini belum ada petani yang membudidayakan pohon halubi (E. conferta) secara massal, buah halubi (E. conferta) biasanya dibiarkan membusuk ditangkainya dan berjatuhan. Padahal, buah halubi (E. conferta) ini dapat dijadikan makanan alternatif, masyarakat sudah mulai menggunakan tanaman halubi (E. conferta) sebagai oleholeh souvenir dan makanan khas berupa buah manisan, Hasilnya berdampak positif dengan adanya peningkatan konsumsi dan pemanfaatan halubi ( $E$. conferta). Tanaman ini seluruh bagiannya dapat digunakan, dari batang kambium dapat dimakan, buah dapat juga dimakan meskipun rasanya masam dan buah yang digunakan sebagai pengganti asam atau dibuat menjadi manisan, asinan, dan sirup, daun dimanfaatkan oleh masyarakat lokal sebagai atap rumah.

Pengamatan karakter morfologis bertujuan untuk mendapatkan data sifat dasar fenotip (Bermawie, 2005). Pengamatan morfologis berguna untuk mengetahui pengembangan budidaya tanaman salak melalui pemuliaan. Untuk itu perlu dilakukan identifikasi morfologis tanaman salak (Pulakiang et al., 2017). Dalam tujuan menginformasikan karakteristik morfologis tanaman salak, dapat dilihat berdasarkan ciri vegetatif dan ciri generatifnya agar dapat diperoleh deskripsi dan klasifikasi tanaman salak tersebut (Santoso, 1990).

Informasi mengenai kelimpahan dan keragaman pada level spesies memang sangat penting bagi kelestarian komunitas alami yang ada di suatu ekosistem. Kelestarian spesies akan terancam jika organisme dengan keragaman genetik yang rendah memiliki kemampuan adaptasi terhadap kondisi lingkungan yang terbatas. Sehingga, jika perubahan lingkungan terjadi secara ekstrim maka spesies dengan kelimpahan dan keragaman tinggi tetapi keragaman genetiknya rendah dapat mengalami kepunahan (Herawati et al., 2012). Berdasarkan uraian di atas serta pentingnya dan kekhawatiran hilangnya salah satu sumber 
daya alam khas milik indonesia seperti asam halubi (E. conferta) ini maka perlu dilakukan penelitian tentang distribusi dan karakteristik morfologi asam halubi (E. conferta) yang terdapat di Desa Binanga Dua Kecamatan Silangkitang Kabupaten Labuhanbatu Selatan. Sehingga informasi ini dapat menjadi pengetahuan masyarakat sekitar untuk ikut langsung membantu mempertahankan keberadaan populasi halubi (E. conferta) di alam dan memanfaatkan tumbuhan ini dengan bijak.

\section{METODE}

\section{Waktu dan Tempat}

Penelitian ini dilaksanakan pada bulan Februari-Maret 2019. Lokasi penelitian berada di desa Binanga Dua, Kecamatan Silangkitang Kabupaten Labuhanbatu Selatan. Pengamatan karakteristik morfologi sampel koleksi halubi dilakukan di Laboratorium Ekologi FKIP Universitas Labuhanbatu dan Konfirmasi identifikasi sampel dibantu oleh Herbarium Medanense Universitas Sumatera Utara.

\section{Prosedur Penelitian}

Pelaksaan koleksian sampel halubi dilakukan dengan metode jelajah. Hasil koleksi dari lapangan di bawa ke laboratorium Ekologi FKIP Universitas Labuhanbatu untuk diidentifikasi dengan menggunakan buku-buku acuan identifikasi diantaranya:; The Malayan species of Salacca. Gardens Bulletin, Singapore (Furtado, 1949); Edible Medicinal and NonMedicinal Plants (Lim, 2011); Genera Palmarum: The evolution and classification of palms (Dransfield et al., 2008); Collection of Illustrated Tropical Plant (Watanabe and Corner, 1969), Plant Resources of South East Asia (Valkenburg \& Bunyapraphatsara, 2002a), Medicinal and poisonous plants (Valkenburg \& Bunyapraphatsara, 2002b), dengan mengamati karakter morfologi berikut :

a) Daun : susunan daun, bentuk daun, pangkal daun, ujung daun, kisaran panjang daun $(\mathrm{cm})$, kisaran lebar daun $(\mathrm{cm})$.

b) Batang : panjang batang, lebar batang, jarak ruas batang.

c) Bunga : letak bunga, panjang bunga jantan $(\mathrm{cm})$, panjang bunga betina $(\mathrm{cm})$, panjang tangkai bunga jantan ( $\mathrm{mm}$ ), jumlah mahkota bunga, jumlah benang sari.

d) Buah : bentuk buah, diameter buah.

e) Biji : bentuk biji, warna biji.

Serta untuk mengetahui wilayah distribusi tumbuh halubi dilakukan dengan bantuan alat GPS (Global Positioning System).

\section{HASIL DAN PEMBAHASAN \\ Distribusi Halubi (Eleiodoxa conferta)}

Berdasarkan koleksi halubi hanya ditemukan tumbuh pada 2 lokasi (Lihat gambar 2.), dimana lokasi ke-1 berada di sekitar perkebunan sawit milik masyarakat desa dan lokasi ke 2 berada di hutan dekat pemukiman masyarakat desa, berikut jabaran morfologi halubi ( $E$. conferta) yang ditemukan di keseluruhan desa Binanga Dua Kecamatan Silangkitang Kabupaten Labuhanbatu Selatan.

Dari gambar 2 peta distribusi halubi (E. conferta) dapat diketahui bahwa halubi di desa Binanga Dua tumbuh di ketinggian 2500-3000 mdpl, Tanaman ini ditemukan tumbuh berdampingan dengan hutan tanaman industri (karet, kepala sawit) milik masyarakat. Ketinggian tempat akan berpengaruh terhadap pertumbuhan dan produksi tanaman terkait dengan intensitas sinar matahari.

Halubi Eleiodoxa conferta memiliki keeratan dengan genus Salacca (Lim, 2011), Informasi menurut Astuti (2007); Wijana et al, (1997) tanaman salak Salacca dapat dapat tumbuh dan berproduksi dengan baik mulai dari dataran rendah hingga dataran tinggi (50 - 
$800 \mathrm{~m} \mathrm{dpl)}$ pada tanah gembur dengan struktur tanah berpasir.. Berdasarkan persyaratan tumbuh tersebut, dapat disimpulkan bahwa salak genus Salacca tidak dapat tumbuh dengan baik apabila iklim kondisi faktor fisik kimia lingkungan tidak sesuai untuk mendukung tumbuh kembangnya. Dalam rangka rencana budidaya, mengetahui faktor-faktor iklim lingkungan yang sesuai syarat tumbuhnya perlu dilakukan.

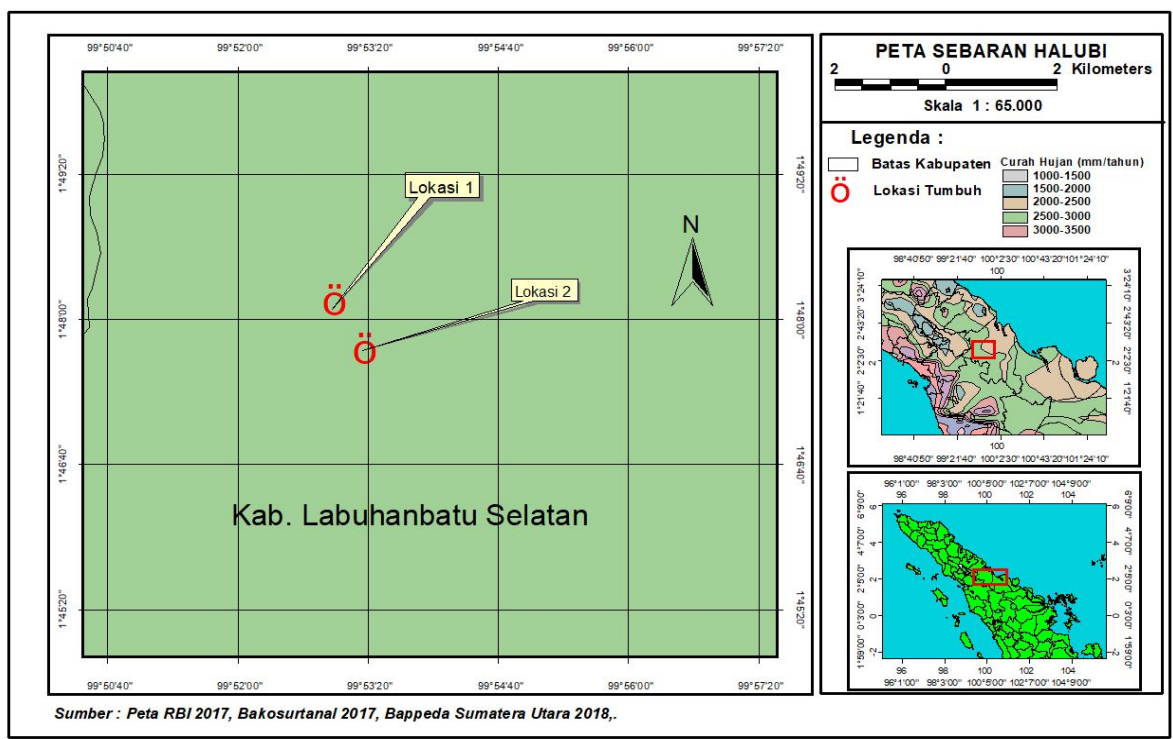

Gambar 2. Distribusi Halubi (Eleiodoxa conferta) di sekitar Labuhanbatu Selatan

Pada saat penelitian dilakukan (Februari - April 2019) curah hujan masuk kedalam kategori rendah rata-rata $(20-100 \mathrm{~mm})\left({ }^{*}\right.$ Kategori berdasarkan peta analisis BMKG 2019). Kondisi curah hujan yang rendah ini berpengaruh terhadap penyebaran distribusi halubi di alam, terbukti dari titik tumbuh halubi di desa Binanga Dua ini yang hanya ditemukan 2 lokasi. Informasi Astuti (2007); Ashari (1992) agar genus Salacca tumbuh optimum membutuhkan curah hujan rata-rata $200-400 \mathrm{~mm} /$ bulan. Apabila curah hujannya lebih tinggi dari $400 \mathrm{~mm} /$ bulan akan merugikan tanaman, karena banyak bunga/buah yang membusuk.

Selain pengaruh faktor lingkungan, hal unik yang membedakan halubi dengan tumbuhan salak-salakan lain adalah cara hidupnya, dimana halubi E. conferta memiliki tipe cara hidup hapaxanthic (Loo, 2011) yang bermakna setelah berbuah, spesies ini akan mati dan akan dilanjutkan oleh perkecambahan individu anakan baru. Kondisi cara hidup seperti inilah yang juga menyebabkan sulitnya penyebaran dan perkembangan halubi pada suatu daerah.

\section{Parameter Lingkungan (Pendukung Distribusi Halubi (Eleiodoxa conferta) Di Lokasi Penelitian)}

Dari hasil pengukuran diperoleh informasi bahwa penyebaran distribusi (Eleiodoxa conferta) yang ditemukan di desa Binanga Dua tidak luput dari pengaruh parameter lingkungannya (tabel 1.).

Perolehan data pengukuran faktor fisik-kimia lingkungan masih tergolong sesuai bagi kehidupan halubi. Sesuai informasi Dransfiled et al, (2008) bahwa Eleiodoxa conferta adalah pohon palem rawa air tawar dataran rendah, berumpun, dan sangat berlimpah di daerah hutan rawa gambut. Astuti (2007); Wijana et al, (1997); Ashari, (1992) menjelaskan tanaman salak genus Salacca akan tumbuh optimum pada tanah yang subur, gembur dan lembab dengan keasaman tanah $(\mathrm{pH})$ antara $4-7,5$ dan tidak tahan terhadap sinar matahari penuh $(100 \%)$ oleh sebab itu penyinaran matahari hanya antara 50 - $80 \%$, kelembaban udara tinggi 80 - 
$90 \%$ dan suhu $20-30{ }^{\circ} \mathrm{C}$. Berdasarkan data BMKG wilayah Labuhanbatu Selatan (2019), Suhu udara rata-rata $\left(26^{\circ} \mathrm{C}-33^{\circ} \mathrm{C}\right)$, kelembaban udara rata-rata $(80 \%-85 \%)$ lama penyinaran matahari rata-rata berkisar (5-6 jam). Oleh karena itu genus salak ini memerlukan adanya tanaman peneduh lain di sekitarnya.

Tabel 1. Faktor Fisik-Kimia Lingkungan Pada Lokasi Tumbuh Halubi (Eleiodoxa conferta)

\begin{tabular}{lcc}
\hline Parameter & Lokasi 1 & Lokasi 2 \\
\hline Suhu & $30^{\circ} \mathrm{C}$ & $32^{\circ} \mathrm{C}$ \\
Kelembaban Udara & $68 \%$ & $72 \%$ \\
Intensitas Cahaya & 500 & 640 \\
pH Tanah & 5,5 & 6,9 \\
Titik Koordinat & $1^{0} 47^{\prime}, 44,7^{\prime}$ LU & $1^{0} 48^{\prime} 13,8^{\prime \prime} \mathrm{LU}$ \\
& $99^{0} 53^{\prime} 19,66^{\prime} \mathrm{BT}$ & $99^{0} 53,2,2^{\prime} \mathrm{BT}$ \\
Kondisi substrat & tanah gambut muda & tanah liat \\
Deskripsi Lokasi & dekat pemukiman & dekat kebun sawit \\
\hline
\end{tabular}

Selain kondisi parameter fisik-kimia lingkungan, penyebab sulitnya ditemukan distribusi tumbuh halubi kemungkinan disebabkan oleh aktivitas antropogenik yang dilakukan manusia, berupa alih fungsi lahan menjadi perkebunan dan pemukiman. Pada 2 lokasi temuan, diketahui, halubi tumbuh berada dekat dengan pemukiman masyarakat dan perkebunan milik masyarakat sekitar. Rustam (2016); Kizilkaya \& Dengiz (2010); Winanti (1996), menjelaskan bahwa perubahan tutupan lahan seperti penebangan hutan, budidaya tanaman/perkebunan mengakibatkan perubahan sifat biofisik tanah, karena setiap jenis vegetasi memiliki sistem perakaran yang berbeda. merupakan penyebab berubahnya sifat fisik, kimia dan biologi tanah. Oksana \& Huda (2012); Manfarizah et al., (2011); Utaya (2008); Suprayogo et al., (2004) Rusaknya ekosistem lingkungan akan menyebabkan penurunan kualitas daya dukung lingkungan sehingga akan berdampak terhadap keberlanjutan populasi spesies tersebut secara kualitas maupun kuantitas.

\section{Morfologi Halubi Batang}

Batang memiliki batang bulat, tumbuh tegak, beruas-ruas, jarak ruas keruas rata-rata \pm $8 \mathrm{~cm}$, tinggi batang rata-rata $\pm 3-5 \mathrm{~m}$. Permukaan batang kasar, batang berduri, warna duri putih kekuningan dan muncul berkelompok, jumlah duri pada batang rata-rata \pm 125 , panjang duri $\pm 2-5,3 \mathrm{~cm}$, batang muda memiliki kulit batang berwarna hijau, dan batang tua berwarna hijau kecoklatan hingga coklat. Sekilas halubi (E. conferta) terlihat mirip dengan salak (Salacca zalacca), Menurut Herawati et al., (2012) batang salak pondoh termasuk pendek dan hampir tidak kelihatan secara jelas, karena selain ruas-ruasnya padat juga tertutup oleh pelepah daun yang tumbuh memanjang. Batang tanaman salak lemah dan mudah rebah, pada batangnya dapat tumbuh tunas yang berakar sendiri, yang bila dibiarkan tumbuh di batang, tunas-tunas tersebut dapat tumbuh menjadi rumpun tanaman salak yang besar.

\section{Daun}

Daun memiliki Panjang daun rata-rata $\pm 22 \mathrm{~cm}$, panjang daun pendek rata-rata \pm 10 $\mathrm{cm}$, Lebar daun rata-rata $\pm 4,3 \mathrm{~cm}$, bentuk daun tanaman halubi berbentuk panjang dengan permukaan daun berduri halus, jumlah duri daun rata-rata \pm 45 , daun muda berwarna hijau, dan daun tua berwarna coklat tua. Pangkal daun halubi (E. conferta) bentuknya panjang dan ujung daunnya runcing. Susunan tulang daun berhadapan dan sejajar. Menurut Furtado (1949), Daun pelepah keluar dari batang perdu dan mempunyai daun berwarna hijau yang 
lurus dengan susunan saling berhadapan sepanjang rata-rata menurut Lim (2011) \pm 1.5 meter dengan rata-rata \pm lebar 3-5 cm, panjang pelepah daun sekitar 2,5-3 meter dan pelepah akan mati apabila ketiak pelepah telah mengeluarkan bunga dan buah, pelepah daun ditutupi oleh duri dengan panjang rata-rata $\pm 5-7 \mathrm{~cm}$.

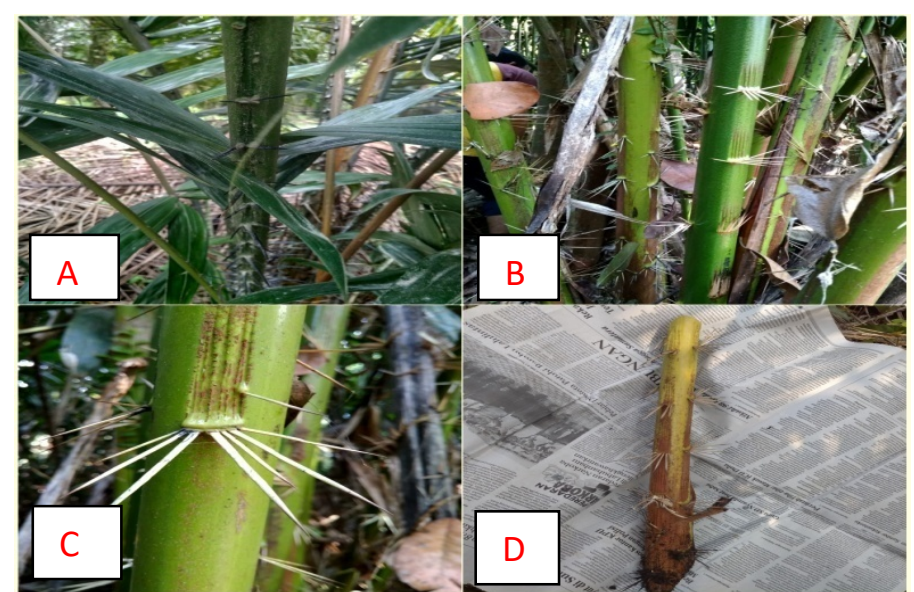

Gambar 1. Morfologi Batang Halubi (a) batang halubi, (b) arah tumbuh duri pada batang, (c) pelepah batang (sumber dokumen pribadi)

Tabel 2.Karakter Morfologi Halubi pada2 Lokasi Pengamatan Desa Binanga Dua

\begin{tabular}{llll}
\hline Karakter Morfologi & Lokasi 1 & Lokasi 2 \\
\hline Daun & Panjang & $22,4 \mathrm{~cm}$ & $21,9 \mathrm{~cm}$ \\
& Lebar & $4,1 \mathrm{~cm}$ & $4,4 \mathrm{~cm}$ \\
& Warna Permukaan & Hijau Tua & Hijau Tua \\
& $\begin{array}{l}\text { atas daun } \\
\text { Bentuk ujung daun }\end{array}$ & Meruncing & Meruncing \\
& Jarak antar duri & $3-5 \mathrm{~cm}$ & $3-5 \mathrm{~cm}$ \\
\hline Duri & & & \\
Batang & Panjang duri & $2,5-5 \mathrm{~cm}$ & $2-5 \mathrm{~cm}$ \\
& Jumlah duri (dalam & Total $\pm 50-60$ & Total $\pm 50-60$ \\
& 20 cm) & & \\
& Duri Uk.besar & \pm 16 & \pm 15 \\
& Duri Uk.kecil & \pm 10 & \pm 10 \\
\hline Buah & Warna kulit & kecoklatan & kecoklatan \\
& Warna daging buah & kuning & kuning \\
& Rasa & asam & asam \\
& diameter & $\pm 4 \mathrm{~cm}$ & $\pm 4 \mathrm{~cm}$ \\
& Jumlah dalam & $\pm 25-40$ & $\pm 25-40$ \\
& tandan & & Coklat kehitaman \\
& Warna & Coklat kehitaman & $\pm 2-3,5 \mathrm{~cm}$ \\
\hline Biji & diameter & $\pm 2-3,5 \mathrm{~cm}$ & \\
& & &
\end{tabular}

\section{Bunga}

Hasil pengamatan penelitian, perbungaan halubi ditemukan Dioceus (berumah dua), dimana bunga jantan dan bunga betina terpisah. Herawati et al., (2017) menjelaskan salak yang bertipe rumah 2 memiliki bunga jantan maupun betina tersusun dalam tipe perbungaan tongkol. Bunga jantan tersusun seperti genteng, mempunyai benang sari yang banyak berwarna kuning. Sebelum mekar baik bunga jantan maupun bunga betina diselubungi oleh seludang. Bunga betina mempunyai mahkota umumnya merah muda. Bunga terminal, 
terletak di ketiak ujung batang tersusun rapat, bentuk bunga panjang tegak keatas muncul berkelompok, jumlah bunga dalam 1 tandan 12 bunga. Furtado (1949) menjelaskan bunga jantan berukuran 25-40 cm, morfologi bunga betina mirip dengan jantan hanya sedikit lebih pendek dari ukuran bunga jantan. Lim (2011) Selubung perbungaan (infloresence) bunga jantan dan betina tumbuh dari dasar, menghasilkan buah yang banyak dengan bentuk buah cenderung memulat, dengan satu atau kadang-kadang dua biji.

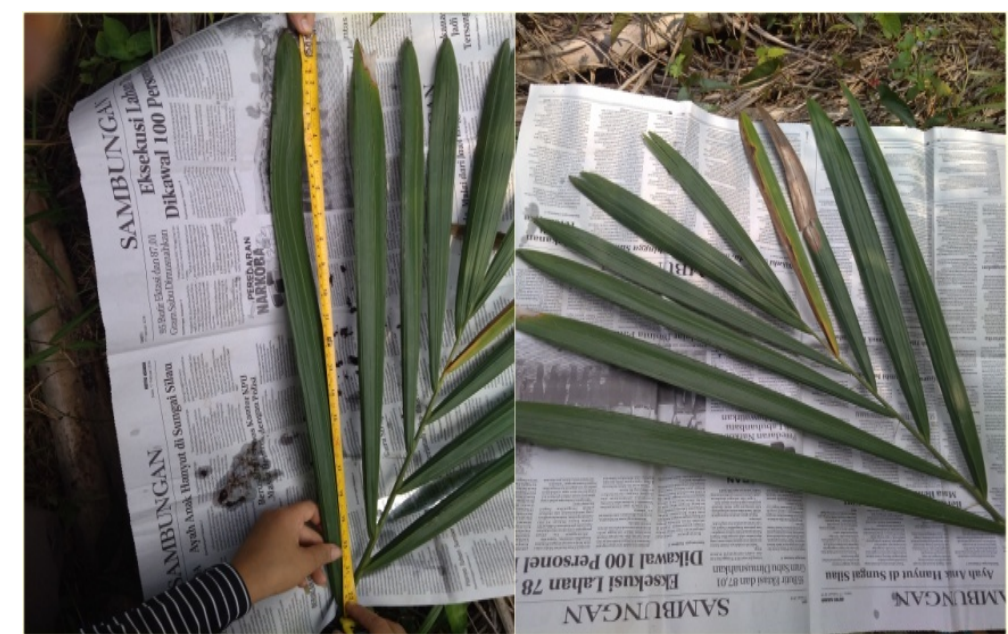

Gambar 2. Morfologi Daun Halubi (Sumber Dokumen Pribadi)

Perbedaan halubi dengan salak, menurut Suskendriyati et al., (2000). Bunga jantan, terdiri dari stamen tanpa putik, banyak, rapat, panjang, tersusun seperti genteng, simetri radial, Bunga betina hanya menghasilkan putik, berbentuk agak bulat. Mempunyai mahkota dan mata tunas dengan satu putik dan bakal biji yang tersusun dalam kuntum. Panjang bunga seluruhnya $\pm 20-30 \mathrm{~cm}$, warna hijau kekuningan lalu merah dan sebelum mekar sempurna bunga sudah berwarna kehitaman.

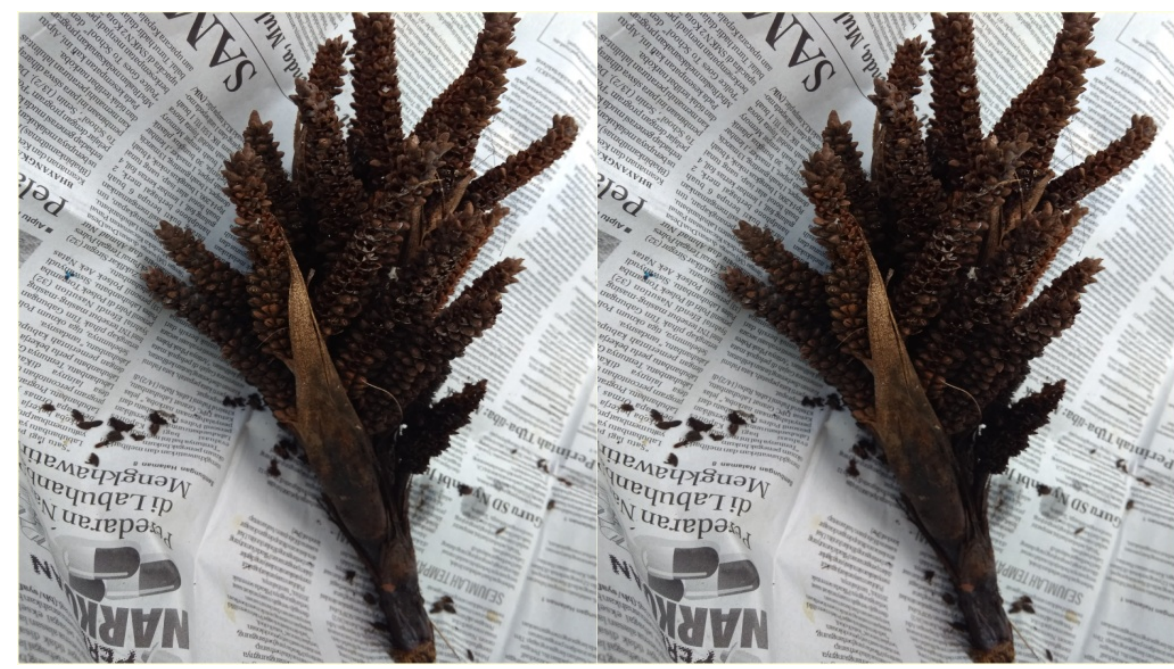

Gambar 3. Morfologi Bunga Halubi (Sumber Dokumen Pribadi)

\section{Buah}

Buah memiliki berukuran $\pm 2-5 \mathrm{~cm}$, panjang buah rata-rata $\pm 3,5 \mathrm{~cm}$, rata-rata lebar buah $\pm 2,7 \mathrm{~cm}$, tebal buah $\pm 2,7 \mathrm{~cm}$, bentuk buah bulat - lonjong bersisik, jumlah buah satu tandan $\pm 35-40$ buah, panjang batang buah rata-rata $\pm 14 \mathrm{~cm}$, warna buah kuning s.d coklat tua, kulit tebal dan keras, jumlah sisik buah sekitar \pm 80 . Menurut Lim (2011); Furtado (1949) 
buah berdiameter 3-5 cm. Buah muncul berkelompok dalam tandan. Satu tandan besar berisi 300-400 buah. Tandan besar tersusun dari tandan-tandan kecil yang berisi sekitar 25-40 buah. Kulitnya buah bersisik berwarna hijau kuning gading saat masih muda dan berubah cokelat saat matang, Dransfield et al., (2008) buah memiliki sarcotesta yang tebal sulit dipisahkan dari dasar biji. Tekstur kulit keras dan lebih tebal dari pada kulit salak

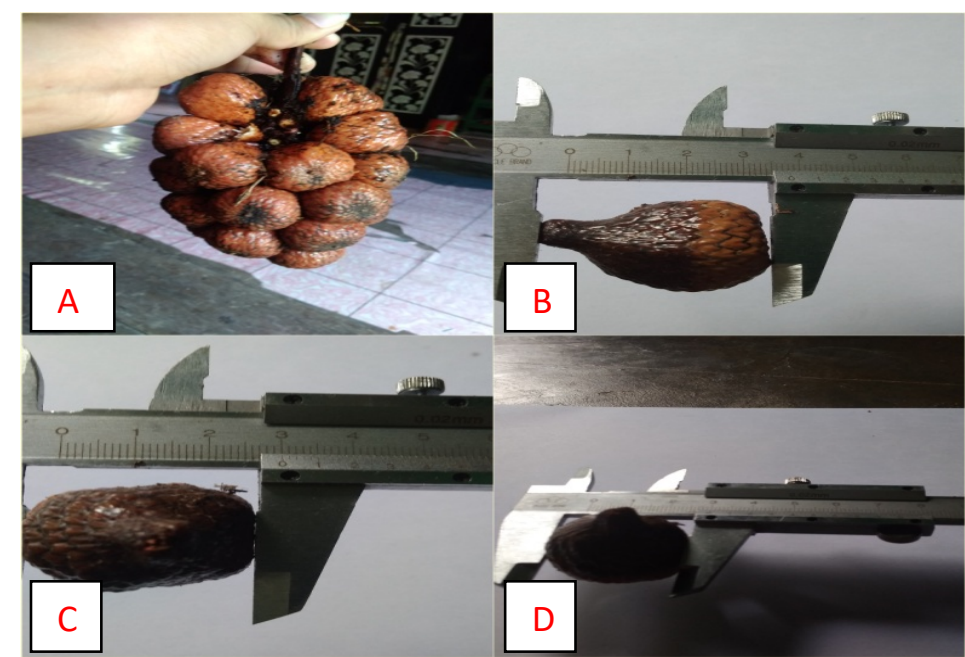

Gambar 4. (a) Satu tandan buah halubi, (b) panjang buah, (c) lebar buah, (d) tebal buah (Sumber dokumen pribadi)

\section{Biji}

Morfologi biji pada semua lokasi penelitian yang ditemukan memiliki karakter morfologi yang sama. Biji pada umumnya berdiameter antara 2-3 cm. Warna biji kuning kecoklatan sampai coklat tua, biji sulit di pisahkan dari daging buah karena memiliki sarcotesta yang tebal. Biji halubi (E. conferta) memiliki kemiripan yang hampir sama dengan salak, seperti yang dijelaskan. Menurut Annisaurrohmah et al., (2014). Biji salak biasanya berbentuk lonjong, berwarna coklat tua. Pada tiap satu buah memiliki satu biji (soliter) yang dibalut sarcotesta.

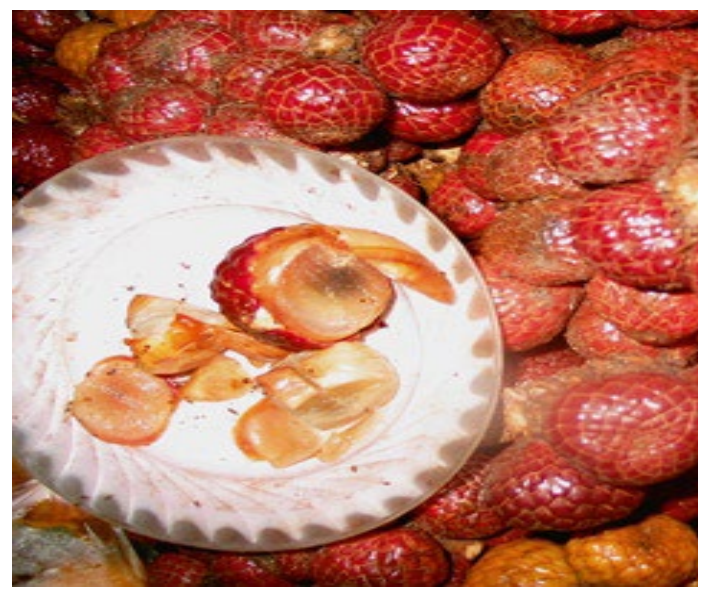

Gambar 5. Morfologi Sarcotesta Halubi

\section{KESIMPULAN}

Penelitian ini dapat diperoleh bahwa tidak ditemukan perbedaan karakteristik morfologi dari buku acuan identifikasi, sehingga dapat disimpulkan bahwa halubi yang tumbuh di lokasi penelitian merupakan Eleiodoxa conferta. Distribusi lokasi tumbuh halubi 
di desa Binanga Dua yang ditemukan hanya ada 2 lokasi yaitu pada koordinat titik I ( $1^{0} 47^{\prime}$

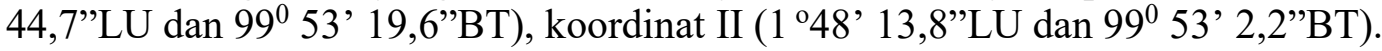

\section{DAFTAR PUSTAKA}

Afriani, S., Idiawati N, Destiarti L, Arianie L. (2014). Uji Aktivitas Antioksidan Daging Buah Asam Paya (Eleiodoxa conferta Burret) Dengan Metode Dpph Dan Tiosianat. $J K K$, Vol3(1): 49-56.

Annisaurrohmah, Herawati W, dan Widodo P. (2014). Keanekaragaman Kultivar Salak Pondoh di BanjarnegaraCultivar Diversity of Salak Pondoh in Banjarnegara, Buletin Biosfera, Vol 2(31): 71-83.

Bermawie, N. (2005). Karakterisasi Plasma Nutfah Tanaman. Buku Pedoman Pengelolaan Plasma Nutfah Perkebunan. Pusat Penelitian dan Pengembangan Perkebunan. Bogor: 38-52.

Dransfield, J., N. W. Uhl, C. B. Asmussen, W. J. Baker, M. M. Harley \& C. E.Lewis (2008). Genera Palmarum: The Evolution and Classification of Palms. Kew Publishing. 744 pp.

Furtado, C. X. (1949). The Malayan species of Salacca. Gardens Bulletin, Singapore, 12(2): $378-401$.

Herawati W, Chasanah T, Kamsinah. (2012). Karakteristik Salak Lokal Banyumas (Salacca zalacca (Gaert.) Voss) Sebagai Upaya Pelestarian Spesies Indigenous. Fakultas Biologi. Universitas Jendral Soedirman. Prosiding Seminar Nasional. November 2012.

Herwin, Arta, Nur, Dewi. (2000). Studi Morfologi dan Hubungan Kekerabatan Varietas Salak Pondoh (Salacca zalacca (Gaert.) Voss.) di Dataran Tinggi Sleman. Jurnal Bioderversitas Volume 1, Nomor 2: 59 - 64.

Kizilkaya, R and Dengiz O. (2010). Variation of Use And Land Cover Effects On Some Soil Physico-Chemical Characteristics And Soil Enzyme Activity Zemdirbyste. Agriculture. 97(2): 15-24

Lim, T K. (2011). Eleiodoxa conferta. Edible Medicinal and Non-Medicinal Plants. Springer, Dordrecht: $396-398$

Loo, AHB. (2011). Rediscovery in Singapore of Salacca affinis griff. (Arecaceae). Nature in Singapore. Volume 4:123-126

Manfarizah, Syamaun, Nurhaliza S. (2011). Karakteristik Sifat Fisika Tanah di University Farm Station Bener Meria. J.Agrista. Vol 15(1): 1-9

Oksana, I., dan Huda M.U. (2012). Pengaruh Alih Fungsi Lahan Hutan Menjadi Perkebunan Kelapa Sawit Terhadap Sifat Kimia Tanah. Jurnal Agroforestri. Vol 3(1): 29-34.

Pulakiang AR, Polii-Mandang JS, Sompotan S. (2017). Beberapa Karakter Morfologis Tanaman Salak (Salacca zalacca (Gaert) Voss) Di Kampung Bawoleu, Kecamatan Tagulandang Utara, Kabupaten Kepulauan Siau Tagulandang Biaro. Jurnal Eugenia. Volume 23 No. 2 Juni 2017

Rustam., Umar H., Yusran. (2016). Sifat Fisika Tanah Pada Berbagai Tipe Penggunaan Lahan Di Sekitar Taman Nasional Lore Lindu (Studi Kasus Desa Toro Kecamatan Kulawi Kabupaten Sigi Sulawesi Tengah). Warta Rimba. 4(1):132-138.

Santoso, H.B (1990). Salak Pondoh. Yogyakarta: Penerbit Kanisius.

Suprayogo, D., Widianto, Purnomosidi, P., Widodo, R.H., Rusiana, F., Aini, ZZ., Khasanah, N., dan Kusuma, Z. (2004). Degradasi Sifat Fisik Tanah Sebagai Akibat Alih Guna Lahan Hutan Menjadi Sistem Kopi Monokultur: Kajian Perubahan Makroporositas Tanah. J.Agrivita 26 (1): 60-68.

Utaya S. (2008). Pengaruh Perubahan Penggunaan Lahan Terhadap Sifat Biofisik Tanah dan Kapasitas Infiltrasi di Kota Malang. Forum Geografi. 22 (2): 99 - 112 
Valkenburg, J. L. C. H. V., Bunyapraphatsara, N, (2002). a. Plant Resources of South East Asia 12(1). Medicinal and poisonous plants 2. Prosea Fondation.Bogor-Indonesia: pp. 58-79.

Wardani. (2008). Keragaman Potensi Tumbuhan Berguna Di Cagar Alam Mandor, Kalimantan Barat. Jurnal Penelitian Hutan Dan Konservasi Alam. Volume 5(3): 251266 